\title{
Human Lung Angiotensin Converting Enzyme
}

\author{
PURIFICATION AND ANTIBODY PREPARATION
}

\author{
Joan Friedland, Emanuel Silverstein, Martin Drooker, \\ and Charlotte Setton, Laboratory of Molecular Biology, Departments of \\ Medicine and Biochemistry, State University of New York, Downstate \\ Medical Center, Brooklyn, New York 11203
}

A B S T RA C T To enable its immunohistologic localization, angiotensin converting enzyme (EC 3.4.15.1) from human lung was solubilized by trypsinization and purified $\sim 2,660$-fold to apparent homogeneity from a washed lung particulate fraction. The specific activity of pure enzyme was estimated to be 117 $\mu \mathrm{mol} / \mathrm{min}$ per $\mathrm{mg}$ protein with the substrate hippurylL-histidyl-L-leucine. Consistent with previously described lung enzyme studies, catalytic activity was strongly inhibited by EDTA, $O$-phenanthroline, SQ 20,881 , and $S Q 14,225$ and increased by $\mathrm{CoCl}_{2}$. SQ 20,881 was a somewhat more potent inhibitor than SQ 14,225 , unlike rabbit lung enzyme. The Michaelis constant $\left(K_{\mathrm{m}}\right)$ with hippuryl-L-histidyl-L-leucine was $1.6 \mathrm{mM}$. The molecular weight was estimated at 150,000 from sucrose density gradient centrifugation. Sodium dodecyl sulfate polyacrylamide gel electrophoresis revealed a single polypeptide chain estimated at 130,000 daltons.

Rabbit antibody to human lung enzyme was prepared by parenteral administration of pure angiotensin-converting enzyme in Freund's adjuvant. Rabbit antibody to human lung angiotensin-converting enzyme appeared to crossreact weakly with the rabbit enzyme and strongly inhibited the catalytic activity of the enzymes from human serum, lung, and lymph node. The specificity of the rabbit antibody and purity of the final human lung enzyme preparation was suggested by the single precipitin lines obtained by radial double immunodiffusion, and by the coincidence of enzyme catalytic activity and immunoreactivity on polyacrylamide gel electrophoresis, with both relatively pure and highly impure enzymes. Generally applicable sensitive analysis of acrylamide gels for immunoreactivity (and subsequently for any other activity) by use of intact gel slices in radial double

\footnotetext{
Address reprint requests to Dr. Silverstein.

Received for publication 24 September 1980 and in revised form 12 December 1980.
}

immunodiffusion was devised. Human lung enzyme was very tightly bound to and catalytically active on anti-human enzyme antibody covalently bound to Sepharose 4B, and could not be readily dissociated without inactivation. Antibody to human lung angiotensin converting enzyme has permitted tissue localization of the enzyme, which appears to be clinically useful in diseases associated with abnormal abundance of angiotensin-converting enzyme in tissues, such as sarcoidosis.

\section{INTRODUCTION}

Angiotensin-converting enzyme (ACE) ${ }^{1}$ (E.C. 3.4.15.1; peptidyldipeptide hydrolase) catalyzes the conversion of the decapeptide angiotensin I to the biologically potent octapeptide angiotensin II (vasopressor, aldosterone regulator, and dipsogen), and inactivates the vasodepressor bradykinin $(1,2)$. ACE is predominantly localized at the luminal surface of endothelial cells which line blood vessels $(3,4)$. Administration of ACE inhibitors significantly lowers blood pressure in hypertension in the rat and man $(5,6)$. Granulomatous lymph nodes from sarcoidosis patients (7) and spleen from patients with Gaucher disease $(8,9)$ contain large quantities of ACE, which is also generally increased in the patients' serum (7-12). The sources of excess serum ACE were believed to be the sarcoidosis epithelioid cell and Gaucher cell (13), both mononuclear phagocytes that normally contain negligible ACE (14), but are markedly inducible for ACE synthesis in culture $(15,16)$. In order to determine the cellular location of the abnormally abundant enzyme, ACE was purified to apparent homogeneity from human lung and an antibody with high affinity for ACE was prepared, as described in this communication. Utilization of this antibody for localization of ACE in

\footnotetext{
${ }^{1}$ Abbreviation used in this paper: ACE, angiotensin-converting enzyme.
} 
epithelioid and Gaucher cells is described elsewhere (17-19).

\section{METHODS}

Materials. Sepharose CL-6B-200, L-histidyl-L-leucine, native and cross-lined bovine serum albumin, $O$-phthaldialdehyde, DEAE-cellulose (coarse grade), glycine, Tris, Coomassie Brilliant Blue $\mathrm{R}, N, N, N^{\prime}, N^{\prime}$-tetramethylethylenediamine, 2-mercaptoethanol, sucrose, trypsin (bovine pancreatic, twice crystallized, dialyzed and lyophilized, 10,000 $\mathrm{N} \alpha$-benzoyl-L-arginine ethyl ester $\mathrm{U} / \mathrm{mg}$ protein) and soybean trypsin inhibitor were purchased from Sigma Chemical Co., St. Louis, Mo. Ammonium sulfate and other salts were reagent grade from J. C. Baker Chemical Co., Phillipsburg, N. J. Hippuryl-L-histidyl-L-leucine was purchased from Bachem Inc., Fine Chemicals, Torrance, Calif. Nonidet was a gift from Bethesda Research Laboratories, Rockville, Md. The phosphorylase b protein marker was a gift of Dr. Karl Lanks, Downstate Medical Center. Acrylamide and $N, N^{\prime}$-methylene bis-acrylamide were purchased from Eastman Kodak Co., Rochester, N. Y.; the acrylamide was recrystallized from ethyl acetate prior to use. Sodium dodecyl sulfate (SDS) (Matheson, Coleman \& Bell, Rutherford, N. J.) was crystallized from ethanol prior to use. Highly purified urea was purchased from Schwartz/Mann, Div. Becton, Dickinson \& Co., Orangeburg, N. Y. Complete Freund's adjuvant was obtained from Difco Laboratories, Detroit, Mich. Human lung was obtained at autopsy. H-Pyr-Trp-Pro-Arg-Pro-Gln-Ile-ProPro-OH (SQ 20,881) and D-3-mercapto-2-methylpropanoyl-Lproline (SQ 14,225) were kindly provided by S. J. Lucania of the Squibb Institute for Medical Research, Princeton, N. J.

$A C E$ assay. Conditions were previously described (15, 20 ) and were based on a fluorimetric assay and the substrate hippuryl-L-histidyl-L-leucine $(21,22)$. $1 \mathrm{U}$ of ACE was defined as $1 \mu \mathrm{mol} / \mathrm{min}$ of His-Leu released from hippuryl-Lhistidyl-L-leucine ( $5 \mathrm{mM}$ initial concentration) at $37^{\circ} \mathrm{C}$. ACE activity was determined as follows: to a $13 \times 100-\mathrm{mm}$ glass test tube was added $240 \mu \mathrm{l}$ of buffered substrate containing $0.104 \mathrm{M}$ potassium phosphate, $\mathrm{pH} 8.3 ; 0.3125 \mathrm{M} \mathrm{NaCl}$; $5.21 \mathrm{mM}$ hippuryl-L-histidyl-L-leucine, and $0.7 \mathrm{mg}$ bovine serum albumin. The solution was warmed to $37^{\circ} \mathrm{C}$ in a water bath and reaction was initiated by addition of $10 \mu$ l of diluted $\mathrm{ACE}$ in $0.05 \mathrm{M}$ potassium phosphate, $\mathrm{pH}$ 8.3. The reaction mixture was stirred in a vortex mixer for $1 \mathrm{~s}$ and incubated at $37^{\circ} \mathrm{C}$ for $15 \mathrm{~min}$. Reaction was terminated by addition of $1.45 \mathrm{ml} 0.28 \mathrm{~N} \mathrm{NaOH}$, and the product His-Leu was quantified fluorimetrically (20). ACE activity was limited so that no more than $3 \%$ or $37.5 \mathrm{nmol}$ of substrate were hydrolyzed during the reaction. For tissue ACE assay bovine serum albumin $(2.8 \mathrm{mg} / \mathrm{ml}$ reaction mixture $)$ was added to stabilize ACE activity, since erratic, generally lower activity was otherwise obtained at lower protein concentrations.

Antibody-antigen interaction. Assessment of antibodyantigen interaction was made by measurement of the degree of inhibition of the enzymic catalysis. For this purpose and all other uses anti-ACE serum was placed at $56^{\circ} \mathrm{C}$ for $30 \mathrm{~min}$ to lower the residual ACE activity generally to between 2 and 3 $\mathrm{nmol} / \mathrm{min}$ per $\mathrm{ml}$ and destroy complement activity. ACE was reacted with anti-ACE for $30 \mathrm{~min}$ at $37^{\circ} \mathrm{C}$ in $200 \mu \mathrm{l}$ of $0.375 \mathrm{M} \mathrm{NaCl}-0.125 \mathrm{M}$ potassium phosphate, $\mathrm{pH} 8.3$, and assayed for residual activity. Reaction was initiated by addition of $0.05 \mathrm{ml}$ of $25 \mathrm{mM}$ hippuryl-His-Leu; incubation was for $15 \mathrm{~min}$. The assayed activity was corrected for residual ACE activity in the rabbit antiserum.

Protein was assayed by the method of Lowry et al. (23), using bovine serum albumin as standard.
Column separations. Coarse grade DEAE-cellulose was washed prior to use (24) and then equilibrated with $10 \mathrm{mM}$ potassium phosphate, $\mathrm{pH}$ 7.8. Sepharose CL-6B-200 was also equilibrated with this buffer before use.

Polyacrylamide gel electrophoresis. $7 \%$ acrylamide gels were prepared essentially according to Davis (25). For immunologic studies $3.75 \%$ acrylamide gels were prepared according to the Canalco method (Ames Co., Div. Miles Laboratories, Elkhart, Ind.) as follows: one part of a $50-\mathrm{ml}$ solution (7.5 g acrylamide and $200 \mathrm{mg}$ of $N, N^{\prime}$-methylene bis-acrylamide in distilled deionized water) was diluted with 1 part buffer $(24 \mathrm{ml} 1 \mathrm{~N}$ HCL, $18.15 \mathrm{~g}$ Trizma base and 115 $\mu l \quad N, N, N^{\prime}, N^{\prime}$-tetramethylethylenediamine in $100 \mathrm{ml}, \mathrm{pH}$ $8.8-9.0$ ) and two parts $0.166 \%$ potassium persulfate. The solution was deaerated briefly. Standard gel tubes were filled to provide a $6-\mathrm{cm}$ gel and $50 \mu \mathrm{l}$ of water layered on the top of each gel. Gels were polymerized in the dark for $30 \mathrm{~min}$. The electrophoresis buffer was as specified for the standard pH 8.9 gels. No spacer or sample gels were used. Preelectrophoresis of the gels were carried out until the bromphenol blue marker was off the gels to remove any impurity that might interfere with the antigen-antibody reaction when gels were analyzed immunologically. The electrophoresis was performed at $3 \mathrm{~mA} /$ tube for $40 \mathrm{~min}$, unless otherwise specified. The gels were removed from the tubes and frozen at $-75^{\circ} \mathrm{C}$ until they were sliced at $1-\mathrm{mm}$ intervals, using a precooled multiple blade cutter.

ACE assay of acrylamide gel fractions. Individual gel slices were extracted with moderate agitation for 1-2 h at $0^{\circ} \mathrm{C}$ in $0.2 \mathrm{ml}$ of $0.125 \mathrm{M}$ potassium phosphate, $\mathrm{pH} 8.3$, $0.375 \mathrm{M} \mathrm{NaCl}$ containing $0.7 \mathrm{mg}$ bovine serum albumin. The assay reaction was initiated in the extract by addition of 0.05 $\mathrm{ml}$ of $25 \mathrm{mM}$ hippuryl-L-histidyl-L-leucine.

SDS acrylamide gel electrophoresis (7\% gels) was carried out (26) with crosslinked albumin, and phosphorylase b markers. $100-\mu \mathrm{l}$ samples of ACE as well as markers were heated at $60^{\circ} \mathrm{C}$ for $1 \mathrm{~h}$ after addition of $1 \mu \mathrm{l} 2$-mercaptoethanol, $1 \mathrm{mg}$ SDS, and $24 \mathrm{mg}$ urea (27). Samples were subjected to electrophoresis for $4 \mathrm{~h}$ at $8 \mathrm{~mA}$ per gel tube.

Sucrose density gradient centrifugation was done according to Martin and Ames (28) using rabbit muscle aldolase as a marker.

Partial purification of antiserum. An immunoglobulin fraction was isolated from heat-inactivated $\left(30 \mathrm{~min}\right.$ at $\left.56^{\circ} \mathrm{C}\right)$ rabbit anti-human lung ACE serum by two ammonium sulfate precipitations and carboxymethyl and DEAE-cellulose column chromatography (29).

Radial double immunodiffusion (30). Immunodiffusion plates $(35 \times 10 \mathrm{~mm}$, Falcon Labware, Div. Becton, Dickinson \& Co., Oxnard, Calif.) were prepared using $1.5 \%$ noble agar containing $0.375 \mathrm{M} \mathrm{NaCl}-0.125 \mathrm{M}$ sodium phosphate, $\mathrm{pH}$ 8.3 , and $0.02 \%$ sodium azide as a preservative. $1 \mathrm{ml}$ of boiled agar at $50^{\circ} \mathrm{C}$ was added to each plate. Seven wells were cut into each plate with a No. 2 cork borer using an hexagonal template with a center well for antibody. Enzyme samples were added directly to the peripheral wells, or when acrylamide gels were analyzed for immunoreactivity the intact gel slices were transferred to the peripheral wells and then moistened by adding 7-10 $\mu$ l of $1: 1: 2$, glycerol: $1.5 \mathrm{M} \mathrm{NaCl}$ $-0.3 \mathrm{M}$ sodium phosphate buffer, $\mathrm{pH} 8.3$ : water. $4 \mu \mathrm{l}$ of the immunoglobulin fraction (29) of rabbit anti-human lung ACE containing $64 \mu \mathrm{g}$ of protein was added to the center well. The plates were then incubated at $37^{\circ} \mathrm{C}$ at $100 \%$ humidity to prevent dehydration of the discs during development. Precipitin bands were less strongly developed at $40 \mathrm{~h}$ than at $90 \mathrm{~h}$. However, assay for residual enzyme was more satisfactory at $40 \mathrm{~h}$ than at $90 \mathrm{~h}$. 
TABLE I

Purification of Human Lung ACE

\begin{tabular}{lccccc}
\hline \multicolumn{1}{c}{ Procedure } & Vol & $\begin{array}{c}\text { Total } \\
\text { units }\end{array}$ & $\begin{array}{c}\text { Units/milligram } \\
\text { protein }\end{array}$ & Yield & Purification \\
\hline & $m l$ & & & $\%$ & \\
Particulate & 680 & 181.7 & 0.048 & 100 & 1 \\
Trypsinization & 680 & 164.0 & 0.044 & 90 & 1 \\
21,000 g supernate & 594 & 152.0 & 0.091 & 83.6 & 2.07 \\
Millipore filtration & 590 & 138.6 & 0.110 & 76.3 & 2.5 \\
DEAE-cellulose & 256 & 93.0 & 1.592 & 51 & 36.2 \\
PTHK ultrafiltration* & 5.2 & 72.2 & 18.8 & 39.7 & 427 \\
Sepharose CL-6B-200) & & & & & 16.5 \\
PTGC ultrafiltration $\ddagger)$ & 2.4 & 30.0 & 75.3 & & 1,711 \\
\hline
\end{tabular}

* 100,000-dalton cut-off (Millipore).

$\$$ 10,000-dalton cut-off (Millipore).

\begin{abstract}
For better visualization of precipitin lines, plates were repeatedly equilibrated with $0.9 \% \mathrm{NaCl}$ for $3 \mathrm{~d}$ to remove non-precipitin protein, stained with $0.25 \%$ Coomassie Brilliant Blue $R$ in 5:5:1, water: methanol: acetic acid and destained with $5 \%$ methanol-7\% acetic acid in water.

Sepharose $4 B$-bound anti-ACE. $30 \mathrm{mg}$ of rabbit antihuman ACE immunoglobulin was reacted with cyanogen bromide-activated Sepharose 4B (Pharmacia Fine Chemicals, Piscataway, N. J.) at a concentration of $20 \mathrm{mg}$ of immunoglobulin $/ \mathrm{ml}$ of hydrated gel. The Sepharose $4 \mathrm{~B}$ gel was hydrated and reacted according to manufacturer's instructions using $0.2 \mathrm{M} \mathrm{NaHCO} \mathrm{Na}_{3}-0.5 \mathrm{M} \mathrm{NaCl}$, pH 8.7 as coupling buffer. After completion of the reaction no protein was detected in the gel supernate. Any unreacted groups were removed by treatment with $0.2 \mathrm{M}$ glycine, $\mathrm{pH} 8$. The gel was washed with several cycles of coupling buffer and $0.5 \mathrm{M}$ $\mathrm{NaCl}-0.1 \mathrm{M}$ acetate, $\mathrm{pH} 4$. Protein measurement of the gel indicated that $>11 \mathrm{mg}$ of antibody was bound to $1.5 \mathrm{ml}$ of wet gel. The capacity of the insolubilized anti-ACE to bind ACE was determined by incubating $40-\mu$ l portions of antiACE gel with $88 \mathrm{mU}$ of ACE for $1 \mathrm{~h}$ at room temperature in a tube with end-over-end mixing. The supernatant solution obtained by $500 \mathrm{~g}$ centrifugation for $10 \mathrm{~min}$, was assayed for ACE.
\end{abstract}

\section{RESULTS}

Purification of ACE. Table I summarizes the purification that was done at $0-5^{\circ} \mathrm{C}$ unless otherwise stated. Approximately $0.5 \mathrm{~kg}$ of lung was cut into small pieces and homogenized in $9 \mathrm{vol}$ of $50 \mathrm{mM}$ potassium phosphate, $\mathrm{pH} 8.3$ in a Lourdes homogenizer (Vernitron Medical Products, Carlstadt, N. J.) or a Waring blender (Waring Products, New Hartford, Conn.). 15-s periods of homogenization were followed by a 30-s pause to allow adequate cooling. This process was repeated several times. Unhomogenized pieces were removed and minced with a scissor and rehomogenized until a relatively smooth homogenate was obtained, which was filtered through two layers of cheesecloth. The filtrate was centrifuged for $10 \mathrm{~min}$ at $1,060 \mathrm{~g}$ and the resultant precipitate, which contained $20 \%$ of activity, was not further purified. The supernate was centrifuged at $21,000 \mathrm{~g}$ for $1 \mathrm{~h}$. The precipitate was washed by resuspension in $200 \mathrm{ml}$ of buffer and recentrifugation. The precipitate $(3.56 \mathrm{~g}$ protein) was suspended in $340 \mathrm{ml}$ of $2 \mathrm{mM}$ potassium phosphate, $\mathrm{pH} 7.8$, to which $86.2 \mathrm{mg}$ of trypsin and 340 ml of $2 \mathrm{mM} \mathrm{CaCl}{ }_{2}$ were added to solubilize ACE (31). The mixture was incubated for $2 \mathrm{~h}$ at $37^{\circ} \mathrm{C}$, transferred to an ice bath, and $86.2 \mathrm{mg}$ of trypsin soybean inhibitor was immediately added. After the mixture was cooled to $\sim 4^{\circ} \mathrm{C}$ it was centrifuged at $21,000 \mathrm{~g}$ for $80 \mathrm{~min}$. If the pellet was not sufficiently compact it was recentrifuged at $39,000 \mathrm{~g}$ for $90 \mathrm{~min}$.

The supernate was subjected to DEAE-cellulose column chromatography after clarification by filtration through a $0.45-\mu \mathrm{m}$ Millipore filter (Millipore Corp., Bedford, Mass.) (Fig. 1). ACE was eluted near the end of a $\mathrm{NaCl}$ gradient at $\sim 0.1 \mathrm{M}$. Fractions with activities $>0.8 \mathrm{U} / \mathrm{mg}$ protein were pooled and concentrated with a 100,000-dalton cut-off filter (Millipore PTHK). The concentrate was subjected to Sepharose CL-6B-200 gel filtration (Fig. 2). Fractions with activities $>21 \mathrm{U} /$ A280 were pooled and concentrated using a 10,000dalton cut-off filter (Millipore PTGC). The specific activity of the concentrate was $75.3 \mathrm{U} / \mathrm{mg}$ protein (12.5 U/ml).

Polyacrylamide gel electrophoresis of the Sepharose CL-6B-200 concentrate revealed two main bands, and one minor protein band. ACE activity was essentially restricted to the larger second main band (Fig. 3). The two main bands were sufficiently separated to permit a final purification using polyacrylamide gel electrophoresis. 24 analytical polyacrylamide gels, each containing $25 \mu \mathrm{l}$ of the final ACE concentrate $(4.2 \mu \mathrm{g}$ protein) were run for $1.5 \mathrm{~h}$ at $3 \mathrm{~mA} / g e l$. The gels were sliced at $1-\mathrm{mm}$ intervals and the slices from the region 


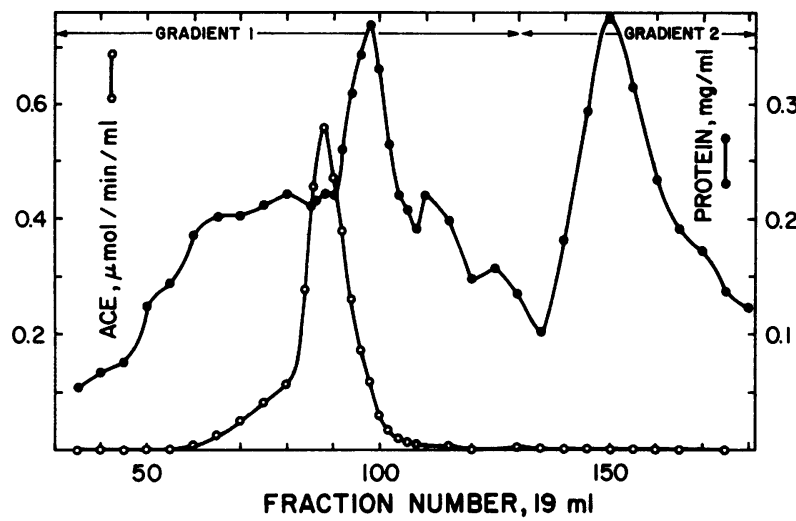

Figure 1 Chromatography of trypsin-solubilized human lung ACE on a $4 \times 33$-cm DEAE-cellulose column. Gradient $1,500 \mathrm{ml} 10 \mathrm{mM}$ potassium phosphate, pH 7.8 and $500 \mathrm{ml}$ buffer- $0.15 \mathrm{M} \mathrm{NaCl}$; gradient $2,500 \mathrm{ml}$ buffer- $0.15 \mathrm{M} \mathrm{NaCl}$ and $500 \mathrm{ml}$ buffer- $0.4 \mathrm{M} \mathrm{NaCl}$.

expected to contain the ACE were extracted with $200 \mu$ l of $10 \mathrm{mM}$ potassium phosphate, $\mathrm{pH} \mathrm{7.8}$. The fractions containing the highest ACE activity were pooled, concentrated, and washed several times with a PTGC filter and stored at $-85^{\circ} \mathrm{C}$.

Properties of ACE. The specific activity of pure ACE was estimated to be $117 \mathrm{U} / \mathrm{mg}$ of protein based on the specific activity obtained in the penultimate step (75.3), the quantity of protein impurity removed in the final polyacrylamide gel electrophoresis step, and the assumption of complete recovery of enzyme activity from the gels. ACE catalysis was modulated as expected by the known inhibitors EDTA and $O$-phenanthroline and the activator $\mathrm{CoCl}_{2}$ (Table II). SQ 20,881 (50\% inhibition, $5.7 \mathrm{nM})$ was a somewhat more potent inhibitor of human lung ACE than SQ



Figure 2 Gel filtration of ACE on a Sepharose CL-6B-200 column. The $2.5 \times 87-\mathrm{cm}$ column was eluted with $10 \mathrm{mM}$ potassium phosphate, $\mathrm{pH}$ 7.8.

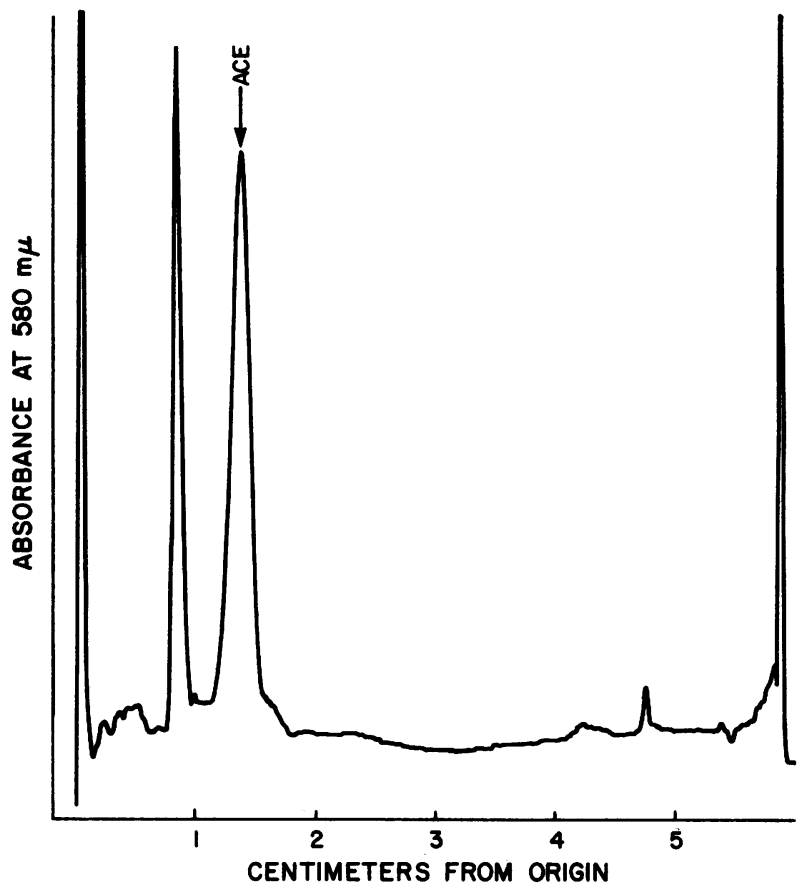

Figure 3 Polyacrylamide gel electrophoresis of human lung ACE following Sepharose CL-6B-200 gel filtration. The absorbance at $580 \mathrm{~nm}$ of protein bands stained with Coomassie Brilliant Blue $\mathbf{R}$ was obtained in a Gilford gel scanner (Gilford Instrument Laboratories, Inc., Oberlin, Ohio). ACE activity, determined on slices of duplicate gels, was virtually limited to the major (second) peak. A peak of $1 \%$ of total activity was present $7 \mathrm{~mm}$ before the major peak and one of $0.3 \%$ of total activity was present $10 \mathrm{~mm}$ after the major peak.

14,225 (50\% inhibition, $11 \mathrm{nM}$ ) (Table III). Preincubation of SQ 20,881 with ACE resulted in a slightly increased inhibition. Preincubation of SQ 14,225 without ACE resulted in a decrease in the degree of inhibition, apparently due to instability of SQ 14,225 at

TABLE II

Effect of Modulators on ACE Catalysis

\begin{tabular}{lcc}
\hline \multicolumn{1}{c}{ Modulator } & Concentration & $\begin{array}{c}\text { ACE activity, } \\
\text { percentage of } \\
\text { control }\end{array}$ \\
\hline EDTA & $0.5 \mathrm{mM}$ & 0.05 \\
EDTA) & $50 \mu \mathrm{M}$ & \\
CoCl ${ }_{2}$ ) & $0.1 \mathrm{mM}$ & 128 \\
$1,10 \mathrm{O}$-phenanthroline & $1 \mathrm{mM}$ & 2.4 \\
\hline
\end{tabular}

ACE was incubated with modulator for $30 \mathrm{~min}$ at $37^{\circ} \mathrm{C}$ prior to assay $(15,20)$, which was initiated by hippuryl-L-histidylL-leucine addition. The final assay mixture contained $0.9 \mathrm{nmol} /$ min ACE activity, $5 \mathrm{mM}$ hippuryl-L-histidyl-L-leucine, 2.8 $\mathrm{mg} / \mathrm{ml}$ bovine serum albumin, $0.3 \mathrm{M} \mathrm{NaCl}$, and $0.1 \mathrm{M}$ potassium phosphate buffer, pH 8.3 (15 min reaction). 
TABLE III

Effect of Inhibitors SQ 14,225 and SQ 20,881 on ACE Catalysis

\begin{tabular}{|c|c|c|c|c|}
\hline \multirow[b]{2}{*}{ Inhibitor } & \multicolumn{2}{|c|}{ Preincubation $37^{\circ} \mathrm{C}$} & \multirow[b]{2}{*}{$50 \%$ Inhibition } & \multirow{2}{*}{$\begin{array}{l}\text { ACE activity, } \\
\text { percentage of } \\
\text { control }\end{array}$} \\
\hline & Time & Reaction mixture & & \\
\hline & $\min$ & & $n M$ & \\
\hline SQ 20,881 & 0 & -Enzyme & 5.7 & \\
\hline SQ 20,881 & 30 & -Hip-His-Leu & 4.8 & \\
\hline SQ 14,225 & 0 & -Enzyme & 11 & \\
\hline SQ 14,225 & 30 & -Hip-His-Leu & 13 & \\
\hline SQ $14,22520 \mathrm{nM}$ & 0 & -Enzyme & & 66 \\
\hline SQ $14,22520 \mathrm{nM}$ & 15 & -Enzyme & & 62 \\
\hline SQ $14,22520 \mathrm{nM}$ & 30 & -Enzyme & & 54 \\
\hline SQ $14,22520 \mathrm{nM}$ & 45 & -Enzyme & & 48 \\
\hline SQ $14,22520 \mathrm{nM}$ & 60 & -Enzyme & & 41 \\
\hline SQ $14,22520 \mathrm{nM}$ & 60 & -Hip-His-Leu & & 62 \\
\hline
\end{tabular}

Assay performed as in Table II. Inhibitor solution at $0^{\circ} \mathrm{C}$ for up to $3 \mathrm{~h}$ before use.

alkaline pH (8.3) (according to data sheet, Squibb Institute for Medical Research); preincubation with ACE protected against the decrease in inhibition (Table III). The Michaelis constant $\left(K_{\mathrm{m}}\right)$ was $1.58 \mathrm{mM}$. Catalytic activity with the substrate angiotensin I (32) in the presence of $0.7 \mathrm{mg}$ bovine serum albumin/ reaction mixture was $1 / 11$ that obtained with hippurylL-histidyl-L-leucine in the standard ACE assay. SDS gels (Fig. 4) of the final purified ACE preparation revealed a single polypeptide chain with a molecular weight estimated at 130,000 . No contaminating proteins were visible. A molecular weight estimate of 150,000 was obtained by sucrose density gradient centrifugation.

Preparation of ACE antiserum. The purified ACE was diluted to $3 \mathrm{ml}$ with Dulbecco's calcium and magnesium-deficient phosphate-buffered saline emulsified with an equal volume of complete Freund's adjuvant and injected four times ( $~ 8 \mu \mathrm{g}$ protein $/ 1.5 \mathrm{ml}$ injection) into the foot pads and muscle of a $3.5 \mathrm{~kg}$ New Zealand white rabbit (Fig. 5). After each immunization the serum ACE activity of the rabbit fell sharply, followed by a slow recovery toward initial levels, suggesting a crossreaction between the rabbit's ACE and its own antibody produced in response to the human ACE used to immunize the rabbit. Incubation of $25 \mu \mathrm{l}$ of rabbit antiserum (heated at $56^{\circ} \mathrm{C}$ for $30 \mathrm{~min}$ to inactivate ACE) collected 2 wk after the third injection, with preimmunization rabbit serum resulted in a $15 \%$ inhibition in the rabbit serum ACE activity, indicating a weak interaction between rabbit serum ACE and rabbit antihuman ACE antibody. The rapid removal of the anti$A C E$ from the rabbit's circulation, indicated by its virtual absence (at day 70, Fig. 5) only $12 \mathrm{~d}$ after obtaining a highly reactive antiserum, was probably the result of such interaction and the removal of immune complex from the circulation.

Inhibition of catalysis by anti-ACE antibody. AntiACE antibody strongly inhibited human ACE catalysis

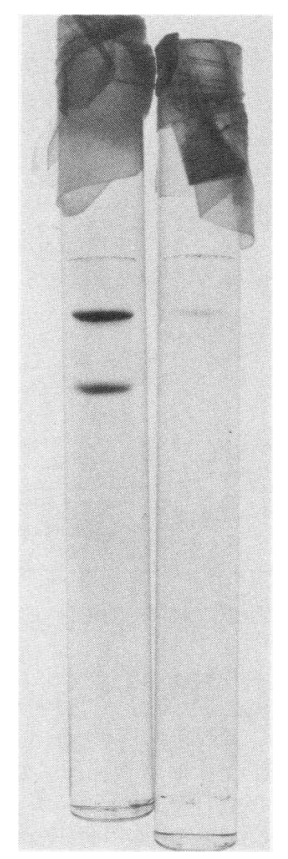

Figure 4 7\% SDS gels of ACE preparations stained with Coomassie Brilliant Blue (see Methods). Highly purified ACE after Sepharose CL-6B-200 gel filtration prior to the final polyacrylamide gel electrophoresis step contains only two bands (left). Homogeneous ACE obtained from the final polyacrylamide gel electrophoresis step contained only the upper band (right). 


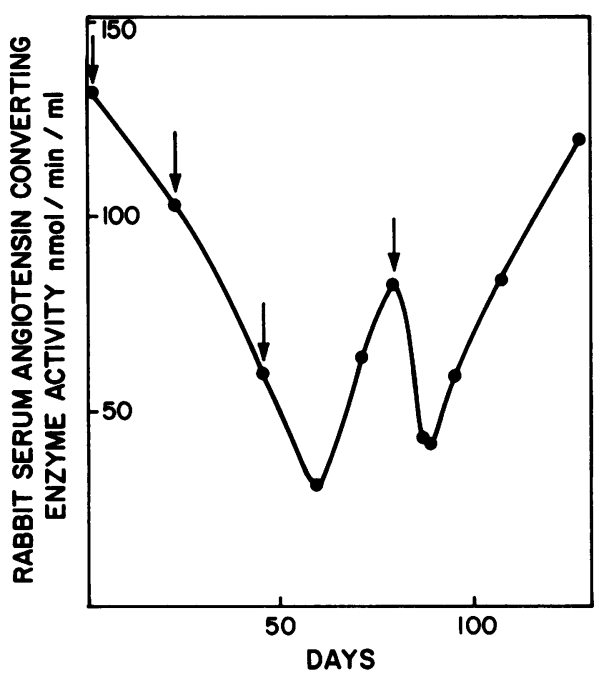

FIgure 5 Transient diminution of rabbit serum ACE activity following repeated immunization with human lung ACE in Freund's adjuvant. The arrows indicate the times of immunization.

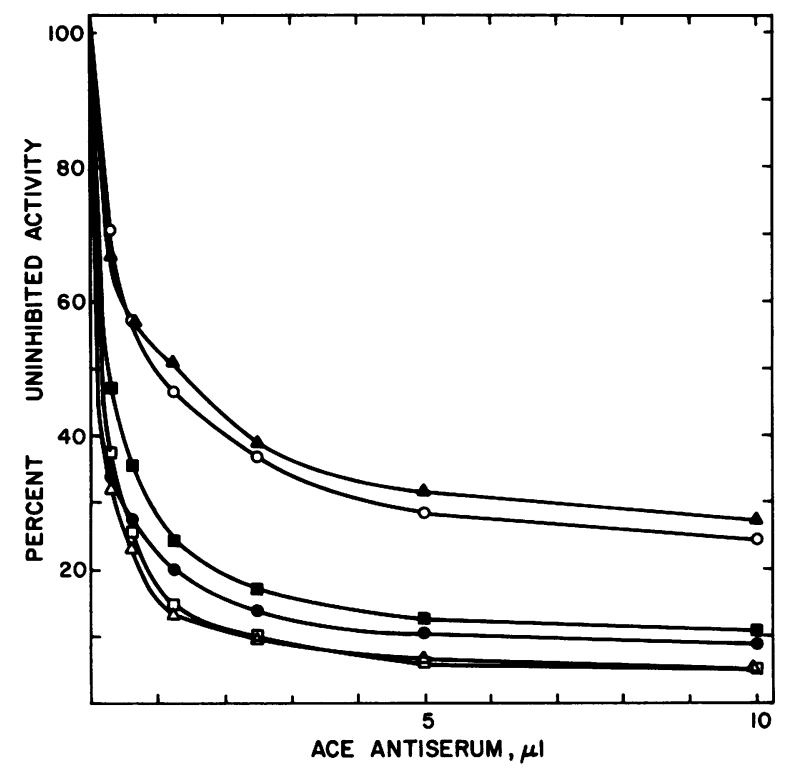

FIgURE 6 Inhibition of human ACE catalytic activity by rabbit antiserum to human lung ACE. See Methods. Type of $\mathrm{ACE}$ and uninhibited activity in $\mathrm{nmol} / \mathrm{min}$ per $\mathrm{ml}$ were: $\boldsymbol{\Delta}$, sarcoidosis lymph node, particulate, 79.5; $\bigcirc$, lung, particulate, 75.5; $\square$, sarcoidosis lymph node, nonidet P40 solubilized, 59.6; 9 , lung, nonidet P40 solubilized, 48.1; $\square$, sarcoidosis serum, 97.5; $\Delta$, Gaucher disease serum, 360. Particulate lung and lymph node ACE was solubilized by shaking in $0.5 \%$ nonidet $\mathrm{P} 40$ for $3 \mathrm{~h}$. The supernate of a $1 \mathrm{~h}$ centrifugation at $31,000 \mathrm{~g}$ at $5^{\circ} \mathrm{C}$ was assayed for ACE activity. Tissue enzyme was assayed in an antiserum incubation mixture containing $\sim 3.5 \mathrm{mg} / \mathrm{ml}$ protein (maintained by serially diluting antiserum in buffer containing $3.7 \mathrm{mg} / \mathrm{ml}$ bovine serum albumin) to stabilize the ACE activity.
(Fig. 6). Serum ACE was most potently inhibited ( $\leqq 95 \%)$. Nonidet P40-solubilized sarcoidosis lymph node and human lung ACE were inhibited up to $92 \%$. Particulate lymph node and lung ACE were inhibited somewhat less strongly than soluble ACE (73-75\%) suggesting greater accessibility of the soluble ACE to anti-ACE. The inhibition of ACE from normal subjects was similiar to that from sarcoidosis and patients with Gaucher's disease; lymph node and lung ACE were similarly inhibited. Human monocyte particulate and soluble ACE synthesized in culture (16) were inhibited similarly.

Radial double immunodiffusion. Sharp, single precipitin lines with merging lines of identity were formed between anti-ACE and ACE of both high and modest purity (Fig. 7). There was no evidence of antibody to impurities in the ACE preparation, suggesting that the human ACE used to raise antibody had a high degree of purity, resulting in high antiserum specificity.

Coelectrophoretic migration of ACE catalytic activity and immunoreactivity. Grossly impure ACE $(\sim 1 \%$ of protein) was subjected to polyacrylamide gel electrophoresis to see if antibody to non-ACE impurities could be detected. Analysis of gel slices revealed a coincidence of the sharp peak of ACE catalytic activity with detectable precipitin reaction (Figs. 8, 9). Precipitin bands with connecting lines of identity were observed only with three to five polyacrylamide gel slices, corresponding to the upper two-thirds of the ACE activity peak. The intensity of the precipitin bands was correlated with the level of ACE activity



Figure 7 Radial double immunodiffusion of human lung ACE and rabbit anti-human lung ACE immunoglobulin. Center well, rabbit anti-human ACE immunoglobulin (6.7 $\mu \mathrm{g}$ protein, $10 \mu \mathrm{l}$ ); A wells, $10 \mu \mathrm{l} \mathrm{ACE,} 0.12 \mu \mathrm{mol} / \mathrm{min}$ activity, $75.3 \mathrm{U} / \mathrm{mg}$ protein; B well, $50 \mu$ l crude trypsinized human lung ACE, $0.082 \mu \mathrm{mol} / \mathrm{min}$ activity, $3.2 \mathrm{U} / \mathrm{mg}$ protein following concentration with an immersible Millipore Cx 30 filter. Only one continuous precipitin arc is seen between the antibody and the two different samples of ACE. 


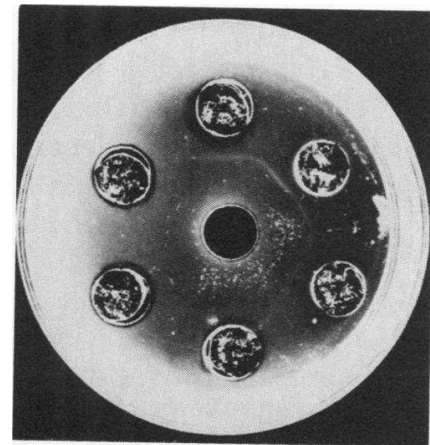

FIGURE 8 Unstained radial double immunodiffusion plate of polyacrylamide gel slices containing angiotensin converting enzyme after $90 \mathrm{~h}$ incubation at $37^{\circ} \mathrm{C}$. The center well contains $4 \mu \mathrm{l}$ rabbit anti-human ACE immunoglobulin. The peripheral wells contain $1-\mathrm{mm}$ thick polyacrylamide disc gel electrophoresis slices containing a grossly impure preparation of ACE. The two strong and one faint precipitin lines correspond to polyacrylamide gels containing peak ACE activity. Lines of identity are seen connecting the three arcs.

recovered. Precipitin reactions were not observed with the numerous proteins devoid of ACE activity that were spread throughout the gel. There was thus no evidence for the presence of any antibody to contaminating non-ACE proteins. These data are therefore consistent with the specificity of the rabbit antibody for human ACE.

Properties of Sepharose-bound anti-ACE. About 96\% of ACE in solution became bound to Sepharoseanti-ACE. Surprisingly, 70-90\% of original activity was recovered in the antibody gel. Under the same conditions, anti-ACE in solution, not covalently bound to Sepharose, resulted in loss of $>90 \%$ of ACE activity. Apparently the active site of ACE bound to insolubilized anti-ACE has relatively free access to substrate and is catalytically active, in contrast to ACE bound to anti-ACE in solution. Perhaps ACE can be intimately bound at several sites by several free anti-ACE molecules, resulting in restricted access of substrate and of catalysis. In contrast, the physical restriction of covalently bound anti-ACE and the distance between fixed antibody molecules may allow binding of only one antibody molecule to each ACE molecule. In addition, the binding site of the insolubilized anti-ACE may not be fully accessible to the ACE active site.

The binding of ACE to insolubilized anti-ACE was exceedingly tight. It was not possible to dissociate significant amount of catalytically active ACE. Less than $7 \%$ of enzyme activity was solubilized by the following dissociating conditions in which ACE was stable at $0^{\circ} \mathrm{C}: 3.8,4$, and $6 \mathrm{M}$ urea in Dulbecco's calcium and magnesium-deficient phosphate-buffered saline, pH 7.2 containing $0.025 \%$ Nonidet P40; $1 \mathrm{M}$ sodium

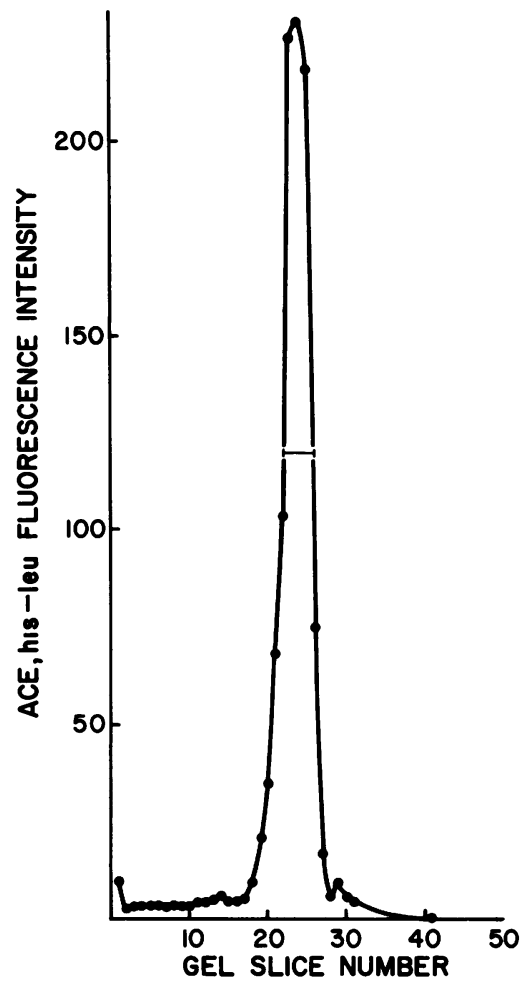

FIGURE 9 Comigration in polyacrylamide gel electrophoresis of ACE catalytic activity and immunoreactivity. $25 \mu \mathrm{l}$ of nonidet solubilized human lung ACE $(0.122 \mathrm{U}, 0.66 \mu \mathrm{mol} /$ min per mg protein) after DEAE-cellulose chromatography was electrophoresed in $3.75 \%$ gels for $40 \mathrm{~min}$ at $2.5 \mathrm{~mA} /$ tube. $1 \mathrm{~mm}$ gel slices were analyzed for immunoreactivity as in Fig. 8 with a 40-h incubation and then for residual catalytic activity (See Methods.) The horizonal bar in the ACE activity peak indicates the gel region containing discernible immunoreactivity. Strongest immunoreactivity was obtained at peak ACE catalytic activity.

trichloracetate, $\mathrm{pH}$ 8; $1 \mathrm{M} \mathrm{NaSCN} ; 2 \mathrm{mM} \mathrm{HCl} ; 1 \mathrm{mM}$ $\mathrm{HCl}$ saturated with $\mathrm{NaCl} ; 0.1 \mathrm{M} \mathrm{NaHCO}_{3}-1 \mathrm{M} \mathrm{NaCl}$, pH 10.6 or pH 11.0. ACE activity of the ACE-insolubilized antibody complexes was generally assayable in high yields following these treatments. ACE was unstable in 3-6 $\mathrm{M}$ guanidine- $\mathrm{HCl}$ and moderately unstable at pH 11. Soluble ACE activity was not obtained by 3-6 M guanidine- $\mathrm{HCl}$ treatment and activity was not recoverable by addition of the eluate to assay buffer containing $0.1 \mathrm{mM} \mathrm{CoCl}_{2}$.

\section{DISCUSSION}

This paper describes preparation to apparent homogeneity of human lung ACE of high specific activity, and preparation of a specific rabbit antibody to it of high affinity. The specific activities we have estimated for pure lung ACE (117 U/mg protein) and obtained 
in the penultimate purification step $(75.3 \mathrm{U} / \mathrm{mg}$ protein) are higher than that reported previously for human lung (9.5 U/mg protein) (31) and human plasma (31.4 $\mathrm{U} / \mathrm{mg}$ protein) (33). Perhaps these differences can be accounted for mainly by the different purification procedures. The different assay conditions $(20,22)$ used to determine specific activity in these different ACE preparations could account for a difference of only $\sim 13 \%$, perhaps due mainly to a similar degree of overestimation of hippuric acid extractability in the spectrophotometric assay (22). ${ }^{2}$

Advantages of trypsin solubilization, in comparison to detergent solubilization, are the lack of optical absorption interference commonly encountered with detergents, and the greater ease of purification to an apparently homogeneous and relatively stable preparation. Trypsin-purified ACE is physically and catalytically very similar to serum ACE. ${ }^{2}$ Indeed, the molecular weight estimated for our trypsin-solubilized human lung ACE is similar to that reported for human plasma ACE (33). The data of Table I do not suggest any significant change in average ACE activity following trypsin treatment. It is rather remarkable that the trypsin treatment of lung particulate ACE used herein results in a discrete molecular species exhibiting a narrow band width in sucrose density gradients and SDS gels comparable to pure marker enzymes, rather than heterogeneous bands, and which is apparently resistant to degradation and inactivation. Inactivation by trypsin of a partially purified human plasma ACE assayed biologically has been reported (34). The effect of trypsin on the structure of lung ACE is currently under investigation. It is not known whether the trypsin treatment altered antigenic determinants on the ACE molecule. However, it is clear that antiACE generated in response to it binds very potently to human ACE that has not been subjected to trypsin treatment.

The anti-ACE antibody described appears to be specific for human ACE since it gave a single precipitin band on immunodiffusion with both relatively pure and grossly impure ACE, and ACE catalytic activity and immunoreactivity were coincident on polyacrylamide gel electrophoresis. These results also suggest the homogeneity of the ACE antigen used to produce the antibody. High antibody affinity for ACE was suggested by the potent inhibition of ACE catalytic activity, and by the very tight binding of ACE to insolubilized antibody, from which it could not be adequately eluted.

The antibody is useful in microscopic localization of ACE by immunohistochemical technique (17, 18), which has diagnostic value in sarcoidosis (19). Ad-

\footnotetext{
${ }^{2}$ Friedland, J., and E. Silverstein. Unpublished observations.
}

ministration of ACE inhibitors such as SQ 20,881 and SQ 14,225 has been shown to lower blood pressure in hypertensive and normotensive subjects $(6,35)$. Goat anti-rabbit ACE antibody (36) decreases the blood pressure in normal and hypertensive rats (37). Rat ACE is inhibited by anti-rabbit ACE antibodies (38). While inhibition of ACE is of value in the therapy of hypertension, it is not clear that anti-human ACE antibody, or another antibody crossreactive with human ACE, might be useful in relieving hypertension in certain circumstances, such as the acute emergency of severe, malignant hypertension unresponsive to other therapy. Potential formidable immunologic (e.g., immune complex formation) and physiologic toxicity and difficulty in fine control might severely limit such an approach.

The phenomenon of diminution of rabbit serum ACE activity by immunization with human ACE antigen in Freund's adjuvant may be reasonably explained by weak binding of rabbit serum ACE by rabbit antiACE antibody and the removal of the antigen-antibody complexes from the circulation. This interpretation is supported by the weak inhibition of rabbit serum ACE catalytic activity by rabbit anti-human ACE antibody. This phenomenon appears to demonstrate the raising of antibodies against "self" protein by an antigenic challenge with a foreign antigen with which it shares antigenic determinants. Such a process is thought to be responsible for disease, such as glomerulonephritis and rheumatic fever following infection with certain streptococcal organisms containing antigens crossreactive with those in man. Our observations demontrate the possibility that crossreactivity between foreign and self protein, besides being potential disease mechanisms, may be a potential therapeutic strategy. Thus, for example, it is conceivable that immunization of man with an ACE that shares antigenic determinants with human ACE may result in auto-anti-ACE antibody formation with resultant decrease in ACE activity and blood pressure. As noted above such an approach might be hazardous and difficult to use in hypertension.

The inhibition of human lung ACE by SQ 20,881 appears to be somewhat more potent than that by SQ 14,225 (Table III). In contrast, the inhibition of rabbit lung ACE by SQ 14,225 is one to two orders of magnitude more potent than that by SQ 20,881 (39). The inhibitory potency of SQ 14,225 is similar with rabbit and human ACE, whereas SQ 20,881 is a more potent inhibitor of human lung ACE (50\% inhibition, $5.7 \mathrm{nM}$ ) than of rabbit lung ACE (50\% inhibition $0.56 \mu \mathrm{m})(39)$. Perhaps these results of inhibitor action on human ACE catalytic activity may provide some understanding of the effectiveness of SQ 20,881 as a antihypertensive agent in man (40). These results also suggest that testing of modulators of ACE activity for possible 
human use might ultimately be done with human lung ACE prior to pharmacological studies in man, since quantitative species differences appear to exist.

Immunodiffusion may be difficult to perform on antigens in low concentration in polyacrylamide electrophoresis gels. Concentration of extracts of the gel slices to a minute volume is difficult to achieve and recovery may be incomplete. This paper describes a more sensitive method of immunodiffusion that utilizes gel slices directly without prior extraction, and that permits subsequent assay of the antigen(s) for comparison with the immunologic precipitin reaction. It may be used to locate small quantities of antigens on gels and to assess the specificity of an antiserum by reacting with an impure antigen preparation at an early stage of purification. Although described for ACE, it should be applicable to other antigens and their antibodies, which are stable under the conditions used, and to other gels.

\section{ACKNOWLEDGMENTS}

We thank Dr. Gerald Schiffman for assistance with immunization procedures, and the National Institutes of Health for grant support (GM 18453, HL 19077).

\section{REFERENCES}

1. Bakhle, Y. S. 1974. Converting enzyme in vitro measurement and properties. In Handbook of Experimental Pharmacology. I. H. Page and F. M. Bumpus, editors. Springer-Verlag, New York. 37: 41-80.

2. Soffer, R. L. 1976. Angiotensin-converting enzyme and the regulation of vasoactive peptides. Annu. Rev. Biochem. 45: 73-94.

3. Ryan, J. W., U. S. Ryan, D. R. Schultz, C. Whitaker, A. Chung, and F. E. Dorer. 1975. Subcellular localization of pulmonary angiotensin-converting enzyme (kininase II). Biochem. J. 146: 497-499.

4. Caldwell, P. R. B., B. C. Seegal, K. C. Hsu, M. Das, and R. L. Soffer. 1976. Angiotensin-converting enzyme: vascular endothelial localization. Science (Wash. D. C.) 191: 1050-1051.

5. Ondetti, M. A., B. Rubin, and D. W. Cushman. 1977. Design of specific inhibitors of angiotensin-converting enzyme: new class of orally active antihypertensive agents. Science (Wash. D. C.) 196: 441-444.

6. Cody, R. J., R. C. Tarazi, E. L. Bravo, and F. M. Fouad. 1978. Haemodynamics of orally-active converting enzyme inhibitor (SQ 14,225) in hypertensive patients. Clin. Sci. Mol. Med. 55: 453-459.

7. Silverstein, E., and J. Friedland. 1976. Markedly elevated angiotensin converting enzyme in lymph nodes containing nonnecrotizing granulomas in sarcoidosis. Proc. Natl. Acad. Sci. U. S. A. 73: 2137-2141.

8. Lieberman, J., and E. Beutler. 1976. Elevation of serum angiotensin converting enzyme in Gaucher's disease. $N$. Engl. J. Med. 294: 1442-1444.

9. Silverstein, E., and J. Friedland. 1977. Elevated serum and spleen angiotensin converting enzyme and serum lysozyme in Gaucher's disease. Clin. Chim. Acta. 74: 21-25.
10. Lieberman, J. 1975. Elevation of serum angiotensin converting enzyme (ACE) in sarcoidosis. Am. J. Med. 59: 365-372.

11. Silverstein, E., J. Friedland, H. A. Lyons, and A. Gourin. 1976. Elevation of angiotensin-converting enzyme. Ann. N. Y. Acad. Sci. 278: 498-513.

12. Silverstein, E., J. Friedland, M. Kitt, and H. A. Lyons. 1977. Increased serum angiotensin converting enzyme activity in sarcoidosis. Isr. J. Med. Sci. 13: 995-1000.

13. Silverstein, E. 1976. Pathogenesis of sarcoidosis: an hypothetical model. Med. Hypotheses 2: 75-78.

14. Silverstein, E., J. Friedland, and C. Setton. 1978. Angiotensin-converting enzyme in macrophages and Freund's adjuvant granuloma. Isr. J. Med. Sci. 14: 314-318.

15. Friedland, J., C. Setton, and E. Silverstein. 1977. Angiotensin converting enzyme: induction by steroids in rabbit alveolar macrophages in culture. Science (Wash. D. C.). 197: 64-65.

16. Friedland, J., C. Setton, and E. Silverstein. 1978. Induction of angiotensin converting enzyme in human monocytes in culture. Biochem. Biophys. Res. Commun. 83: 843-849.

17. Silverstein, E., L. P. Pertschuk, and J. Friedland. 1979. Immunofluorescent localization of angiotensin converting enzyme in epithelioid and giant cells of sarcoidosis granulomas. Proc. Natl. Acad.Sci.U.S.A. 76: 6646-6648.

18. Silverstein, E., L. P. Pertschuk, and J. Friedland. 1980. Immunofluorescent detection of angiotensin converting enzyme in Gaucher cells. Am. J. Med. 69: 408-410.

19. Pertschuk, L. P., E. Silverstein, and J. Friedland. 1981. Immunohistologic diagnosis of sarcoidosis. Detection of angiotensin converting enzyme in sarcoidosis granulomas. Am. J. Clin. Pathol. In press.

20. Friedland, J., and E. Silverstein. 1976. A sensitive fluorimetric assay for serum angiotensin-converting enzyme. Am. J. Clin. Pathol. 60: 416-424.

21. Piquilloud, Y., A. Reinharz, and M. Roth. 1970. Studies on angiotensin converting enzyme with different substrates. Biochim. Biophys. Acta. 206: 136-142.

22. Cushman, D. W., and H. S. Cheung. 1971. Spectrophotometric assay and properties of the angiotensin converting enzyme of rabbit lung. Biochem. Pharmacol. 20: $1637-1648$.

23. Lowry, O. H., N. J. Rosebrough, A. L. Farr, and R. J. Randall. 1951. Protein measurement with the folin phenol reagent. J. Biol. Chem. 193: 265-275.

24. Peterson, A. E., and H. A. Sober. 1962. Column chromatography of proteins: substituted celluloses. Methods Enzymol. 5: 3-27.

25. Davis, B. J. 1964. Part II. Clinical applications: disc electrophoresis-II. Method and application to human serum proteins. Ann. N. Y. Acad. Sci. 121: 404-427.

26. Weber, K., J. R. Pringle, and M. Osborn. 1972. Measurement of molecular weights by electrophoresis on SDSacrylamide gel. Methods Enzymol. 26: 3-27.

27. Lanzillo, J. J., and B. L. Fanburg. 1976. The estimation and comparison of molecular weight of angiotensin I converting enzyme by sodium dodecyl sulfate polyacrylamide gel electrophoresis. Biochim. Biophys. Acta. 439: 125-132.

28. Martin, B. G., and B. N. Ames. 1961. A method for determining the sedimentation behavior of enzymes: application to protein mixtures. J. Biol. Chem. 236: 13721379.

29. Schimke, R. T., R. Palacio, P. Sullivan, M. L. Kiely, C. Gonzales, and J. M. Taylor. 1974. Immunoadsorption of 
ovalbumin synthesizing polysomes and partial purification of ovalbumin messenger RNA. Methods Enzymol. 30: $631-648$.

30. Ouchterlony, O. 1958. Diffusion-in-gel methods for immunological analysis. Prog. Allergy. 5: 1-78.

31. Nishimura, K., N. Yoshida, K. Hiwada, E. Ueda, and T. Kokubu. 1977. Purification of angiotensin I-converting enzyme from human lung. Biochim. Biophys. Acta. 483: 398-408.

32. Friedland, J., and E. Silverstein. 1977. Sensitive fluorimetric assay for serum angiotensin converting enzyme with the natural substrate angiotensin I. Am. J. Clin. Pathol. 68: 225-228.

33. Lanzillo, J. J., and B. L. Fanburg. 1977. Angiotensin I converting enzyme from human plasma. Biochem. J. 16: 5491-5495.

34. Nakahara, M. 1978. Subunits of plasma kininase II generated by plasma kallikrein. Biochem. Pharmacol. 27: 1651-1657.

35. Niarchos, A. P., T. G. Pickering, D. B. Case, P. Sullivan, and J. H. Laragh. 1979. Role of the renin-angiotensin system in blood pressure regulation: the cardiovascular effects of converting enzyme inhibition in normotensive subjects. Circ. Res. 45: 829-837.

36. Das, M., and R. L. Soffer. 1976. Pulmonary angiotensinconverting enzyme antienzyme antibody. Biochem. J. 15: 5088-5092.

37. Markle, R. A., E. H. Sonnenblick, J. M. Conroy, and R. L. Soffer. 1978. Reversal of renovascular hypertension by antibodies specific for angiotensin-converting enzyme. Proc. Natl. Acad. Sci. U. S. A. 75: 5702-5705.

38. Conroy, J. M., H. Hoffman, E. S. Kirk, H. O. Hirzel, E. H. Sonnenblick, and R. L. Soffer. 1976. Pulmonary angiotensin converting enzyme: interspecies homology and inhibition by heterologous antibody in vivo.J. Biol. Chem. 251: 4828-4832.

39. Cushman, D. W., and M. A. Ondetti. 1980. Inhibitors of angiotensin-converting enzyme. Prog. Med. Chem. 17: 41-104.

40. Gavras, H., H. R. Brunner, J. H. Laragh, J. E. Sealey, I. Gavras, and R. A. Vukovich. 1974. An angiotensin converting enzyme inhibitor to identify and treat vasoconstrictor and volume factors in hypertensive patients. N. Engl. J. Med. 291: 817-821. 